\title{
Dehydrogenase Activities of Flooded Soils: A Review (Aktivitas Dehidrogenase pada Tanah Sawah: Review)
}

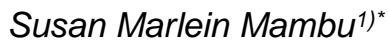 \\ 1) Jurusan Biologi, FMIPA Universitas Sam Ratulangi, Manado 95115 \\ *Email korespondensi: susan.mambu@gmail.com
}

Diterima 21 Juli 2014, diterima utuk dipublikasikan 8 Agustus 2014

\begin{abstract}
The definition of soil quality encompasses physical, chemical and biological characteristics, and it is related to fertility and soil health. Soil enzyme activities are the direct expression of the soil community to metabolic requirements and available nutrients, can be used as soil quality indicators. Among all enzymes in the soil environment, dehydrogenases are one of the most important, and are used as indicator of overall soil microbial activity. Flooded soils present a unique situation since they are predominantly under anaerobic conditions in several physical, chemical, and biological characteristics. Flooding changes the chemistry, microbiological properties, and nutrient supply capacity of soil. In particular, the effect of flooding causes an increase on soil dehydrogenase activity. This review examines selected papers containing soil dehydrogenase activities in flooded soil that could be used to determined effect of flooding on soil dehydrogenase activity.

Keywords: dehydrogenase activities, flooded soils, soil quality
\end{abstract}

\begin{abstract}
Abstrak
Definisi kualitas tanah meliputi faktor fisik, kimia dan biologi, dan terkait dengan kesuburan dan kesehatan tanah. Aktivitas enzim tanah adalah ekspresi langsung dari komunitas tanah untuk melakukan proses metabolik untuk menghasilkan nutrisi, dan dapat digunakan sebagai indikator kualitas tanah. Di antara semua enzim dalam lingkungan tanah, dehydrogenase adalah salah satu yang paling penting, dan digunakan sebagai indikator aktivitas mikroba tanah secara keseluruhan. Tanah sawah dengan kondisi tergenang menyajikan situasi yang unik karena secara fisik, kimia, dan biologi berada dalam kondisi anaerob. Penggenangan menyebabkan terjadinya perubahan secara kimia, mikrobiologi, dan kapasitas pasokan hara tanah. Secara khusus, Efek penggenangan menyebabkan peningkatan aktivitas dehidrogenase tanah. Tulisan ini mengkaji beberapa penelitian mengenai aktivitas dehidrogenase pada tanah sawah, yang dapat digunakan untuk menentukan efek pengenangan terhadap aktivitas dehidrogenase tanah.

Kata Kunci: aktivitas dehidrogenase, tanah sawah, kualitas tanah
\end{abstract}

\section{Introduction}

The soil habitat is defined as the totality of living organisms inhabiting soil, including plants, animals, and microorganisms, and their abiotic environment (Voroney 2007).

Soil is critical components of terrestrial ecosystem, which also include the atmosphere, water, plant and other organisms. Healthy soils are essential for the integrity of terrestrial ecosystems to remain intact or to recover from disturbances, such as drought, climate change, pest infestation, pollution, and human exploitation including agriculture (Ellert et al. 1997).

Soil quality and its degradation depend on a large number of physical, 
chemical, biological, microbiological and biochemical properties. The last two are being the most sensitive since they respond rapidly to changes. The microbiological activities of a soil directly influence ecosystem stability and fertility. It is widely accepted that a good level of microbiological activities has essential roles in maintaining soil quality (Dick and Tabatabai 1992; Bouma 2002).

The physical indicators are related to the organization of the particles and pores, reflecting effects on root growth, speed of plant emergence and water infiltration; they include depth, bulk density, porosity, aggregate stability, texture and compaction. Chemical indicators include $\mathrm{pH}$, salinity, organic matter content, phosphorus availability, cation exchange capacity, nutrient cycling, and the presence of contaminants such as heavy metals, organic compounds, radioactive substances, etc. These indicators determine the presence of soilplant-related organisms, nutrient availability, water for plants and other organisms, and mobility of contaminants. Finally, biological indicators include measurements of micro- and macroorganisms, their activities or functions. Concentration or population of earthworms, nematodes, termites, ants, as well as microbial biomass, fungi, actinomycetes, or lichens can be used as indicators, because of their role in soil development and conservation; nutrient cycling and specific soil fertility. Biological indicators also include metabolic processes such as respiration, used to measure microbial activity related to decomposition of organic matter in soil, and a commonly used index: the metabolic quotient $\left(\mathrm{qCO}_{2}\right)$, defined as the respiration to microbial biomass ratio, which is associated to mineralization of organic substrate per unit of microbial biomass (Anderson 2003, Bastida et al. 2008).

For many years, studies on soil microbiology have been based only on the analysis of the microflora present in the soil, ignoring the influence of extracellular enzymes produced by microorganisms on the decomposition of organic matter and the continuous flux of different elements in the soil, that for Ceron and Melgarejo (2005) understanding and maintaining biodiversity has become an increasingly important field of research, and maintaining critical functions may ultimately be more important than maintaining taxonomic diversity.

Microbial activity is of great importance for biological and biochemical soil processes because it directly influences the transformation of nutrients and organic compost. It is also qualitatively and quantitatively associated with the presence of extracellular hydrolytic enzymes which are important in the process of decomposition and mineralization of organic matter ( Nannipieri et al. 2002). The enzymatic activities play a key role in soil nutrient cycling, which is essential in both the mineralization and transformation of organic matters and plant nutrients in soil ecosystem. Soil enzymes play biochemical functions in the overall process of organic matter decomposition in the system; they are important in catalyzing several reactions, necessary for the life processes of microorganisms in soils, the stabilization of soil structure, the decomposition of organic wastes, organic matter formation, and nutrient cycling, providing an early indication of the history of a soil and its changes in agricultural management (Kandeler et al. 2006). The state of enzymes in the soil was used to describe the location and microenvironment in which it functions and how it was bound or stabilized in the microhabitat. Enzyme activities have been associated with indicators of biogeochemical cycles, degradation of organic matter and soil remediation processes, so they can determine, together with other physical or chemical properties. Because enzymes are difficult to extract from soils and regularly loose their integrity, enzyme activity determination must be made under strict laboratory conditions paying particular attention to temperature control, incubation time, $\mathrm{pH}$ buffer, ionic strength of the solution, and substrate concentration (Gianfreda 
and Ruggiero 2006, Verchot and Borelli 2005, Eldor 2007).

Soil enzyme activities are good indicators or soil quality, since it is closely related to organic matters, physical characteristics, microbial activities and biomass in the soil, provide early information about changes Nevertheless, due to enzyme origin (from bacteria, fungi, plants, and a range of macroinvertebrates), different enzyme locations (intra or extracellular), matrix association (alive or dead cells, clays or and humic molecules) and assay laboratory conditions, it has been demonstrated that it is of great importance to optimize the procedures for enzymatic activity determination in order to obtain the best values and indices according to intrinsic soil properties (Dick and Tabatabai 1992)

There are lots of enzymes in soil, such as oxidoreductases, hydrolases, isomerases, lyases and ligases. Each of them plays key biochemical functions in the overall process of material and energy conversion. Soil dehydrogenases are the major representatives of the oxidoreductase enzymes class and one of the most important are used as an indicator of overall soil microbial activity, because they occur intracellular in all living microbial cells ( $\mathrm{Gu}$ et al. 2009). Moreover, they are tightly linked with microbial oxidoreduction processes (Moeskops et al. 2010).

About $75 \%$ of the 143 million ha of rice land are wetlands, where rice grows under flooded conditions during part or all of the cropping period. Flooding is beneficial to rice cultivation by (1) bringing the soil $\mathrm{pH}$ near to neutrality; (2) increasing availability of nutrients, especially $\mathrm{P}$ and $\mathrm{Fe}$; (3) stimulating biological N,-fixation; (4) depressing soilborne diseases; (5) supplying nutrients from irrigation water; (6) decreasing weed incidence, especially those of C,plants; and (7) preventing water percolation and soil erosion (Watanabe et al. 1987).

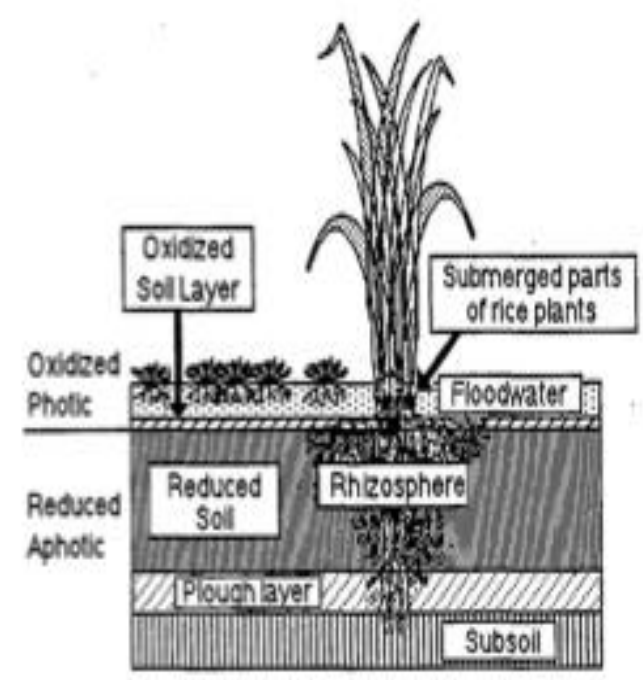

Figure 1. Microenvironments of The Wetland Rice Field Ecosystem (Roger et al. 1993)

Flooding and crop growth lead to the differentiation of macroenvironments differing in physicochemical and trophic properties, in short, a flooded rice field are composed of floodwater, surfaceoxidized soil, reduced soil, rice plants (submerged parts and rhizosphere), plow layer, and subsoil (Fig.1). Although those environments can be macroscopically differentiated, they are more or less continuous. In particular, continuous exchanges take place between floodwater and oxidized soil (Watanabe and Furasaka, 1980).

There is a shift in the soil microflora from predominantly aerobic microorganisms to facultative and obligateanaerobic ones after a soil is flooded. This shift from aerobic to anaerobic microorganisms in flooded soils has been found to cause an increase in soil dehydrogenase activity (Chendrayan et al. 1980, Skujins 1978, Ladd 1978), Active dehydrogenase system has ability to transfers hydrogen from dehydrogenase to molecular oxygen, which use molecular oxygen directly as hydrogen acceptors (aerobic dehydrogenases) or to operate through other hydrogen acceptors (anaerobic dehydrogenases). Their measurement became an indication of the activity of the soil anaerobes (Howard 1972, Pedrazzini and McKee 1983). 
This review focuses on precise description of mentioned the most important soil factors stimulating soil DHA are described below. It also deals with the microbiological management of flooded soil and factors effect DHA in flooded soil.

\section{Soil Dehydrogenase Enzyme Activity}

Soil enzyme activities are very sensitive to both natural and anthropogenic disturbances and show a quick response to the induced changes. Therefore, enzyme activities can be considered effective indicators of soil quality changes resulting from environmental stress or management practices. Long-term productivity and conservation of soil can provide important information about the effects of soil management practices on soil properties. Results showed that levels of organic matter, nutrient cycling, nitrogen and phosphorus were greater in agricultural than uncultivated soils. These specificity makes enzyme useful for comparing microbial communities, monitoring community succession, evaluating the effects of disturbance or ecosystem variables on microbial processes and for studying microbial processes at the molecular level (Sinsabaugh et al. 1991, Dick et al. 1994, Dick 1997).

One of indicator that used for measurement biology activity in soil is dehydrogenase enzyme activity that oxidizes soil organic matter by transferring protons and electrons from substrates to acceptors. It is a part of respiration pathways of soil microorganisms that gave indications of the potential of the soil related to biochemical processes that used for maintaining soil health (Burns 1982).

The intracellular dehydrogenase enzymes belong to the oxidoreductases and catalyse the oxidation of organic compounds by separating two-H atoms. Many specific dehydrogenases act as to transfer the separated $\mathrm{H}$ to either nicotinamide adenine dinucleotide or nicotinamide adenine dinucleotide phosphate. Through these co-enzymes the $\mathrm{H}$ atoms take part in the reductive processes of biosynthesis (Tabatabai 1982). Therefore, the overall dehydrogenase activity of a soil depends on the activities of various dehydrogenases, which are a fundamental part of the enzyme system of all microorganisms (enzymes of the respiratory metabolism, the citrate cycle and $\mathrm{N}$ metabolism).

There are various soil environmental and cultural practices those influence the soil microbial biomass and their activities. The most important soil factors stimulating soil DHA are described below.

1. Soil pH

Generally, enzyme activities tend to increase with soil pH (Moeskops et al. 2010), it is often assumed that $\mathrm{pH}$ may affects soil enzymes level in three different ways (Shuler and Kargi, 2010): by changing in the ionic form of the active sites of the enzymes, which consequently affect the enzyme activity and hence the reaction rate, by altering the three-dimensional shape of enzyme, and by affecting the affinity of the substrate to the enzyme. Soil $\mathrm{pH}$ can significantly affect activities in soil. Trevors (1984) also reported that dehydrogenase activity was decreased when soil samples were adjusted to a lower $\mathrm{pH}$ value from the initial soil $\mathrm{pH}$ pf 7.7. Soil dehydrogenase activity increased in a linear manner when plotted against $\mathrm{pH}$. The correlation coefficient was 0.982 for the relationship. Very little activity was observed below pH 6.6 and above a $\mathrm{pH}$ of 9.5. Thus, the $\mathrm{pH}$ factor is considered to be the best predictor of DHA in the soil environment (Moeskops et al. 2010).

2. Organic matter content

Soil organic matter (OM) has important effects not only on soil enzymes activities but first of all on the activities of microorganism. Soil OM has been considered as an indicator of soil quality (similarly like dehydrogenases,) because of its character of nutrient sink and source that can enhance soil physical and chemical properties, and also promote biological activity (Salazar et al. 2011). Interestingly, not only amount of $\mathrm{OM}$ in the soil is important but most of all its quality, as OM affects 
the supply of energy for microbial growth and enzyme production (Fontaine et al. 2003). Summarizing, the higher content of $\mathrm{OM}$, the more active the soil microorganisms. Microorganisms accelerate the degradation of OM, which is reflected in soil respiration and release of carbon dioxide from the rizosphere (Zhang et al. 2010), thus DHA is positively correlated with OM content. Similarly, increase of DHA with higher microorganisms number was reported (Fontaine et al. 2003).

3. Soil Moisture

Microbial population, their activities and biochemical transformations differ widely in soils of various moisture content. It is demonstrated that soil moisture significantly alters the microbial populations, its activity and the relationships between various parameters (Tiwari et al. 1987). They found that moisture has a profound influence on the dehydrogenase activity. While in the air dried and 1/2 field capacity soils, the activity decreased and stabilized at a very low level, in case of field capacity and waterlogged soil it rose rapidly to a high level. In the case of wetted soil, increased moisture could bring onto solution soluble organic matter, which might be responsible for the increased bacterial population. In the case of the air-dried soil, the decrease may be because of the extrene dryness, which became unfavorable for most bacteria and few could survive in the air-dried soil. Water availability strongly affects on soil microbial activity, community composition, and consequently on soil enzymatic activities. As soils dry, the water potential increases, and as well microbial activity as intracellular enzyme activity slows down (Geisseler et al. 2011). In the case of wet soils, increased moisture could bring into soil solution soluble OM, what might be responsible for increase of bacterial population number. What is important, we should have consciousness that any compound, which alters the number or activity of microorganisms, could on the other hand affect on soil biochemical properties, and ultimately also on soil fertility and plant growth (Subhani et al. 2001). Low water availability can inhibit microbial activity by lowering intracellular water potential, and thus by reducing of hydration and enzymes activity (Wall and Heiskanen, 2003).

4. Temperature

Many researchers have studied effect posed by temperature incubation on soil DHA and or on soil microorganisms abundance. Subhani et al. (2001) and Tansey and Brock (1978) have extensively reviewed the effects of environmental temperatures on microorganisms. Taking into account the important fact that DHA is found inside the viable soil microbial cells only, its activity must be the highest at a temperature close to optimum temperature for microorganisms' growth and their development. Incubation of soil samples at $37^{\circ} \mathrm{C}$ increased soil dehydrogenase activity above the values normally observed at lower temperatures (Casida et al. 1964). It is known that, the rate of enzyme catalysis generally increases with increase in temperature until the unfavorable temperature, at which enzyme becomes denaturized and hence its activity reduces.

5. Fertilization and pesticides amendment

Organic and inorganic fertilizers are commonly used to increase nutrient availability. The balanced fertilization of major elements $(\mathrm{N}, \mathrm{P}, \mathrm{K})$ for plant nutrient could be beneficial for the growth of plant aboveground parts and roots (Chu et al. 2007), and also for improvement of soil structure (Macci et al. 2012). However, fertilization could affect on the population of soil microorganisms and consequently soil enzymatic activities. It is often assumed, that inorganic fertilizers had relatively less effect on soil enzymes activity than organic fertilizers (Chu et al. 2007). Macci et al. (2012) noted, that DHA usually reached higher level in the organic treatments. Soil DHA is an indicator of soil quality and microbial activity and also is the most frequently used to determining the influence of various pollutants (like pesticides or excessive fertilization) on the microbiological quality of soils. 
Anderson et al. (1981) reported that pesticides generally appear to haveno adverse effect on the population of total bacteria in soil expect at concentrations exceeding recommended rates.

6. Heavy metals presence

Heavy metals, even though they are natural constituents of soil, could have long-term hazardous impacts on the health of soil ecosystems, and adverse influences on soil biological processes. Generally, it was assumed that heavy metals can reduce enzyme activity by interacting with the enzyme-substrate complex, denaturing the enzyme protein or interacting with the protein-active groups, they could also affect the synthesis of enzyme microbial cells (Pan \& Yu, 2011). Wilke (1989) reported, the significant declines of dehydrogenase activity in all the above studies indicate it to be the most sensitive parameter for the detection of harmful effects of inorganic pollutans on the soil microbial activity.

\section{Dehydrogenase Activities of Flooded Soils}

Rice is the only major annual food crop (with the exception of aroids) that thrives on land that is water saturated, or even submerged, during part or all of its growth cycle. Wherever conditions are favorable, lowland rice fields are formed into paddies that hold water during the land preparation and rice-growing periods (De Datta 1981). Dehydrogenases are intracellular enzymes catalysing oxidoreductive reactions and are active both in aerobic and anaerobic conditions, although most dehydrogenases are produced by anaerobic microorganisms. Changes in dehydrogenase activity can be due to modifications of the composition of the microbial community as well as of the soil redox potential (Eh) (Dick and Tabatabai 1992)

Yoshida (1975) reviewed, Flooding of rice soils provides a favorable environment for anaerobic microbes and the biochemical changes are varied and numerous. However, a thin surface layer of lowland soil generally remains oxidized and sustains aerobic microbes. The main biochemical processes in flooded soil, however, can be regarded as a series of successive

oxidation-reduction reactions mediated by different types of bacteria. In a complex ecosystem of lowland soils, the soil-water ratio varies and so does the microbial population. Three major types of microbes are present in lowland rice soils in variable proportion:

1. Obligate aerobes that grow only in the presence of molecular oxygen.

2. Obligate anaerobes that grow only in the absence of oxygen.

3. Facultative anaerobes that can grow either with molecular oxygen or anaerobically when supplied with a suitable electron acceptor other than molecular oxygen.

Since microorganisms in flooded soil bring about a large number of biochemical changes, it is difficult to combine all of these processes into a single and unified system. The main biochemical transformations in flooded soils can be regarded as a series of successive oxidation-reduction reactions mediated by different types of bacteria. Flooding a soil alters the character of the microbial flora: aerobes are replaced by facultative and obligate anaerobes. The successive microbial changes are accompanied by a gradual biochemical and chemical reduction of the soil, a lowering of the redox potential (Eh), and a change in $\mathrm{pH}$. Dehydrogenase activity reflects the metabolic activity of the components of the total bacterial population and provides an index of the respiration function associated with their metabolic activity (Pedrazzini and McKee 1984). Pearsall and Mortimer (1939) reported, after flooding a bloom of microbial activity occurs. Following that, microbial activities are retarded gradually due to exhaustion of initially available organic substances, and a steady state is reached between $\mathrm{O}_{2}$ supply through flood water and its consumption beneath the water. Thus, the soil is differentiated into an oxidative layer at the surface, which is several milimeters thick and underlying reductive layer. In irrigated rice fields, the floodwater is an oxicphotic environment. The transition between the floodwater and the 
anoxicaphotic reduced soil is made by the oxidized soil-water layer. The floodwater and the oxidized layer constitute a continuous ecosystem in which four major mechanisms related to soil fertility take place:

1. Biological $\mathrm{N}$-fixation,

2. $\mathrm{N}$ losses by volatilization of $\mathrm{NH} 3$, in relation to the photosynthetic activity of the biomass, and by the nitrificationdenitrification process,

3. Trapping and recycling by the photosynthetic biomass of $\mathrm{C}$ and mineral salts released from the soil and fertilizers, and

4. Transport of nutrients from the soil to the water by the phytoplankton and the primar consumers.

The intensity of these reactions is directy related to the properties of the floodwater and the activity of the biomass (Watanabe and Roger 1985).

A study by Brzezinska et al. (1998) suggested that soil water content and temperature influence dehydrogenase activity indirectly by affecting the soil redox status. The effects of different water content and temperature on the $\mathrm{O}_{2}$ status are expressed by ODR and Eh. Changes of soil water content, temperature and of the soil itself caused changes in soil aeration status towards hypoxia and later to anoxia. An increase in soil water content reduced the aeration status by reducing the air-filled pore spaces available for the diffusion of gases, while an increase in the temperature enhanced demand for $\mathrm{O}_{2}$ in the soil medium thus contributing to a decrease of ODR values. It also accelerated redox transformations under $\mathrm{O}_{2}$ defficiency reducing the redox potential further. The energetic efficiency of anaerobic respiration is much lower than that of aerobic respiration. This is probably the main reason for the close relationship between dehydrogenase activity and soil aeration status. The most pronounced relationship between dehydrogenase activity and the aeration status of the soil is expressed by the use of redox potential. A higher conditioning temperature causes an increase of dehydrogenase activity as well as a greater decrease in redox potential. After flooding the soil, the oxygen present is rapidly exhausted so that a shift of the activity from aerobic to anaerobic microorganisms takes place. Such redox transformations are closely connected with respiration activity of soil microorganisms. Under anaerobic conditions, soils are important sources of a number of greenhouse gases such as $\mathrm{N}_{2} \mathrm{O}, \mathrm{CO}_{2}$, and $\mathrm{CH}_{4}$. The main factors controlling denitrification rates in soil are generally $\mathrm{O}_{2}$ concentration, $\mathrm{NO}_{3}{ }^{-}$concentration and availability of easily metabolizable organic matter. In short, that $\mathrm{NO}_{3}{ }^{-}$reduction to $\mathrm{N}_{2} \mathrm{O}$ and organic matter dehydrogenation to $\mathrm{CO}_{2}$ are related to dehydrogenase activity.

Wlodarczyk et al. (2002) also indicated that the major factor determining soil dehydrogenase activity was its aeration status. Thus the role of the physical factors in determination of the dehydrogenase activity is important as far as they alter the Eh of the soil.

In conclusion, $\mathrm{CO} 2$ and $\mathrm{N}_{2} \mathrm{O}$ production under flooded conditions were related to dehydrogenase activity, which curvilinearly increased with the organic matter content and curvilinearly decreased with Eh. The cumulative $\mathrm{CO} 2$ production increased linearly with soil organic matter content and curvilinearly with dehydrogenase activity and decreased linearly with Eh. The cumulative $\mathrm{N}_{2} \mathrm{O}$ production linearly decreased with Eh and curvilinearly increased with $\mathrm{pH}$ and dehydrogenase activity but linearly with the organic matter content. The $\mathrm{CO}_{2}: \mathrm{N}_{2} \mathrm{O}$ ratio in the gases evolved curvilinearly increased with Eh and curvilinearly decreased with dehydrogenase activity and $\mathrm{N}_{2} \mathrm{O}$ and $\mathrm{CO}_{2}$ production.

Wolińska and Stępniewska (2011) mentioned relationships DHA-Eh have significant negative character, what means that increase of soil DHA level is indirectly connected with decrease of Eh values, as most of microorganisms, which are responsible for DHA prefer rather anaerobic conditions, and belong to obligate anaerobes. What is more, anaerobic conditions are consequence of flooding and decrease of oxygen availability in soil environment. Competition for oxygen limits aerobic 
processes and the subsequent oxygen deficiency creates local anaerobic microsites, which stimulates growth of anaerobic bacteria and finally DHA. In the literature data, it was also assumed (Brzezińska et al. 1998), that DHA is strongly affected by both $\mathrm{Fe}$ as $\mathrm{Mn}$ presence in the soil. Chendrayan et al. (1980) also demonstrated a striking increase in the dehydrogenase activity of soils following flooding. Presumably, the increased dehydrogenase activity was related to the increase in the population of anaerobic microorganisms in flooded soil especially after amendment with rice straw. Iron reduction is probably the most dominant of all redox reaction in a flooded soil. Interestingly, dehydrogenase has been implicated in the microbial reduction of ferric oxides. This would suggest a relationship between iron reduction and dehydrogenase activity in flooded soils.

Pedrazzini and McKee (1984) reported the dehydrogenase activity in the flooded soil with rice plants did not increase unlike that of the flooded soil control. It is possible to consider that the rice roots were competing with the bacteria for nutrients in the soil of the flooded rice soil treatment. The absence of plants in the flooded soil control allowed the bacteria to utilize the nutrients in the soil without competition. The fact that the flooded rice soil plus straw treatment showed the highest dehydrogenase activity suggests that simultaneous availability of $\mathrm{P}, \mathrm{K}$, and $\mathrm{N}$ (fertilization) and C source (rice straw) leads to a strong increase in microbial metabolism. Previous studies have also shown that the incorporation of crop residues into the soil leads to a stimulation of dehydrogenase activity related to increases in bacterial growth.

Soil redox potential have significant distinction in drained and flooded treatments, high redox potential in drained treatment had low levels of dehydrogenase activity and had a high levels of activity in flooded treatments with low redox potential.

\section{Conclusion}

Soil enzymes play key biochemical functions in the overall process of organic matter decomposition in the soil system.
Dehydrogenases are one of the most important, the most sensitive bioindicators and are used as an indicator of overall soil microbial activity, relating to soil quality and fertility. Flooded soils present a unique situation that changes the chemistry, microbiological properties, and nutrient supply capacity of soil, since they are predominantly under anaerobic conditions. The major factor determining soil dehydrogenase activity related to the increase in the population of anaerobic microorganisms in flooded soil especially after amendment with rice straw. Soil physical conditions also have such a strong indirect influence on soil dehydrogenase activity through changes of soil aeration status (expressed either by Eh or by ODR). In conclusion, $\mathrm{CO} 2$ and $\mathrm{N}_{2} \mathrm{O}$ production under flooded conditions were related to dehydrogenase activity, which curvilinearly increased with the organic matter content and curvilinearly decreased with Eh. All of these indicates that, the role of the physical factors in determination of the dehydrogenase activity is important, as far as they alter the redox potential of the soil.

\section{References}

Anderson T (2003) Microbial ecophysiological indicators to asses soil quality. Agriculture, Ecosystems and Environment 98:285-293

Anderson JPE, Armstrong RA, Smith SN (1981) Methods to Evaluate Pesticide Damage to The Biomass of The Soil Microflora. Soli Biology and Biochemistry 13:149-153

Bastida FZA, Hernández H, García C (2008) Past, Present and Future of Soil Quality Indices: A Biological Perspective. Geoderma 147:159171

Bouma J (2002) Land Quality Indicators of Sustainable Land Management Across Scales. Agriculture, Ecosystems and Environment 88:129-136

Brzezinska M, Stepniewska Z, Stepniewski W (1998) Soil Oxygen Status and Dehydrogenase Activity. 
Soil Biology and Biochemistry 30:1783-1790

Burns RG (1982) Enzyme Activity in Soil: Location and Possible Role in Microbial Ecology. Soil Biology and Biochemistry 14:423-427

Burns RG, Dick RP (2002) Enzymes in the Environment: Activity, Ecology and Applications. Marcel Dekker, New York.

Casida L, Klein D, Santoro T (1964) Soil Dehydrogenase Activity. Soil Science 98:371-376

Chendrayan K, Anhyat K, Sethunathan M (1980) Dehydrogenase and Invertase Activities of Flooded Soils. Soil Biology and Biochemistry 12:271-273

Chu H, Lin X, Fujii T, Morimoto S, Yagi K, $\mathrm{Hu}$ J, Zhang J (2007) Soil Microbial Biomass, Dehydrogenase Activity, Bacterial Community Structure In Response To Long-Term Fertilizer Management. Soil Biology and Biochemistry 39:2971-2976

Ceron L, Melgarejo L (2005) Soil Enzymes: Health and Quality Indicators. Acta Biológica Colombiana10 (1):5-18.

De Datta SK (1981) Principles and Practices of Rice Production. WileyInterscience Pub, John Wiley and Sons, Inc, Canada

Dick WA, Tabatabai MA (1992) Significance and Potential Uses of Soil Enzymes. In: Metting FB (ed) Soil Microbial Ecology: Applications in Agricultural and Environmental Management. Marcel Dekker, New York, pp 95-127

Dick RP, Sandor JA, Eash NS (1994) Soil Enzyme Activities After 1500 Years of Terrace Agriculture in The Colca Valley. Peru Agriculture Ecosystem Environment 50:123-131

Dick RP (1997) Soil Enzyme Activities as Integrative Indicators of Soil Health. In: Pankhurts CE, Doube BM, Gupta VVSR (eds) Biological Indicators of Soil Health. CAB International New York, pp 121-156.

Eldor P (2007) Soil Microbiology, Ecology and Biochemistry Third Edition. Chennai, India Academic Press

Ellert BH, Clapperton MJ, Anderson DW (1997) An Ecosystem Perspective of
Soil Quality. In: Gregorich EG, Carter MR (eds) Soil Quality for Crop Production and Ecosystem Health. Elsevier, Amsterdam, pp 115-141

Fontaine S, Marotti A, Abbadie L (2003) The Priming Effect of Organic Matter: A Question of Microbial Competition. Soil Biology and Biochemistry 35:837-843

Geisseler D, Horwath W, Scow K (2011) Soil Moisture and Plant Residue Addition Interact In Their Effect On Extracellular Enzyme Activity. Pedobiologia 54:71-78

Gianfreda L, Ruggiero P (2006) Enzyme Activities in Soil. In: Nannipieri $P$ and Smalla $K$ (eds) Nucleic Acids and Proteins in Soil. Springer, Heidelberg, Germany, pp 257-311

Gu Y, Wag P, Kong C (2009) Urease, Invertase, Dehydrogenase and Polyphenoloxidase Activities In Paddy Soils Influenced By Allelophatic Rice Variety. European Journal of Soil Biology, 45:436-441

HOWARD PJA (1972) Problems in The Estimation of Biological Activity in Soil. Oikos 23:235-240

Kandeler E, Mosier A, Morgan J, Milchunas D, King J, Rudolph S, Tscherko D (2006) Response of Soil Microbial Biomass and Enzyme Activities to The Trescient Elevation of Carbon dioxide in a Semi-arid Grassland. Soil Biology and Biochemistry 38:2448-2460

Ladd JN (1978) Origin and Range of Enzymes in Soil. In: Burns RG (ed) Soil Enzymes. Academic Press London, UK pp 51-96

Macci C, Doni S, Peruzzi E, Masciandro G, Mennone C and Ceccanti B (2012). Almond Tree and Organic Fertilization for Soil Quality Improvement In Southern Italy. Journal of Environmental Management, 95:215-222

Moeskops B, Buchan D, Sleutel S, Herawaty L, Husen E, Saraswati R, Setyorini D, De Neve S(2010) Soil Microbial Communities and Activities Under Intensive Organic and Conventional Vegetable 
Farming In West Java, Indonesia. Applied Soil Ecology 45:112-120

Nannipieri P, Kandeler E, Ruggiero P (2002) Enzyme Activities and Microbiological and Biochemical Processes in Soil. In: Burns RG, Dick, RP (eds) Enzymes in the Environment: Activity, Ecology and Applications. Marcel Dekker, New York pp 1-33

Pan $\mathrm{J}$ and $\mathrm{Yu} L$ (2011) Effects of $\mathrm{Cd}$ or/and $\mathrm{Pb}$ On Soil Enzyme Activities and Microbial Community Sructure. Ecological Engineering 37:1889-1894

Pearsall WH, Mortimer CH (1939) Oxidation-Reduction Potentials in Waterlogged Soils, Natural Waters and Muds. Journal of Ecology 27:483501

Pedrazzini FR, McKee KL (1984) Effect of Flooding on Activities of Soil Dehydrogenases and Alcohol Dehydrogenase in Rice. Soil Science Plant Nutrition 30(3):359-366

Roger PA, Zimmerma WJ, Lumpkin TA (1993) Siol Microbial Ecology. In: Metting FB (ed) Applications in Agricultural and Environmental Management. Marcel Dekker, USA pp 417-455

Salazar S, Sanchez L, Alvarez J, Valverde A, Galindo P, Igual J, Peix A, SantaRegina I (2011).Correlation Among Soil Enzyme Activities Under Different Forest System Management Practices. Ecological Engineering 37:1123-1131

Shuler M, Kargi F (2010) Bioprocess Engineering Basic Concepts. PrenticeHall Incorporation, Englewood Cliffs, New Yersey, USA. ISBN-10: 0130819085

Sinsabaugh RL, Antibus RK, Linkins AE (1991) An Enzymic Approach to The Analysis of Microbial Activity During Plant Litter Decomposition. Agric Ecosyst Environ 34:43-54

Skujins J (1978) History of Abiontic Soil Enzyme Research. In: Burns RG (ed) Soil Enzymes. Academic Press London, UK pp 1-33

Subhani $A$, Changyong $H$, Zhengmiao $Y$, Min L , El-ghamry A (2001) Impact of Soil Environment and Agronomic Practices
Microbial/Dehydrogenase Enzyme Activity In Soil. A Review. Pakistan Journal of Biological Sciences 4:333-338

Tabatabai MA (1982) Soil Enzymes. In: Page AL, Miller RH, Keeney DR (eds) Methods of Soil Analysis. Part 2. Chemical and Microbiological Properties. Agronomy No. 9. ASA and SSSA, Madison, WI, pp 903948.

Tabatabai MA (1994) Soil Enzymes. In: Weaver RW, Angle JS, Bottomley PS (eds) Methods of Soil Analysis Part 2. Chemical and Microbiological Properties. SSSA Book Series No. 5. Soil Science Society of America, Madison, WI, pp 775-833

Tansey MR, Brock TD (1978) Microbial Life at High Temperatures: Ecological Aspect. In: Kushner DJ (ed) Microbial Life in Extreme Environment. Academic Press, English, pp 159-216

Tiwari SC, Tiwari BK, Mishra RR (1987). The Influence of Moisture Regimes on The Population and Activity of Soil Microorganisms. Plant and Soil 101:133-136

Trevors, J. (1984). Effect of Substrate Concentration, Inorganic Nitrogen, O2 Concentration, Temperature and pH On Dehydrogenase Activity In Soil. Plant and Soil 77:285-293

Verchot L, Borelli T (2005) Application of Para-Nitrophenol ( $\mathrm{pNP}$ ) enzyme assays in degraded tropical soils. Soil Biology and Biochemistry 37:625-33

Voroney RP (2007) The Soil Habitat. In: Eldor AP (ed) Soil Microbiology, Ecology, and Biochemistry. Elsevier, USA, pp 25-49

Wall A, Heiskanen J (2003). WaterRetention Characteristic and Related Physical Properties of Soil On Afforested Agricultural Land In Finland. Forest Ecology and Management 186:21-32

Watanabe I, Furasaka C (1980) Microbial ecology of flooded rice soils. In: Alexander M (ed)Advances in Microbial Ecology Vol.4, Plenum Press, New York. pp 125-158 
Watanabe I, Roger PA (1985) Ecology of Flooded Rice ffields. In : IRRI (ed) Wetland Soil: Characterization, Classification, and Utilization. IRRI Proceeding of Workshop, Los Banos, Philippines. pp 229-243

Watanabe I, De Datta SK, Roger PA (1987) Nitrogen cycling in wetland rice soils. In: JR Wilson (ed) Advances in Nitrogen Cycling in Agricultural Ecosystems, C.A.B. International, UK pp 239-256

Wilke BM (1989) Long-term Effects of Different Inorganic Pollutants on Nitrogen Transformation in a Sandy Cambisol. Biology and Fertility of Soil 7:254-258

Wlodarczyk T, Stepniewski W, Brzezinska M (2002) Dehydrogenase Activity, Redox Potential, and Emissions of Carbon dioxide and Nitrous oxide from Cambisols Under Flooding Conditions. Biology and Fertility of Soil 36:200206

Wolińska A, Stępniewska Z (2011) Microorganisms Abundance and
Dehydrogenase Activity As a Consequence of Soil Reoxidation Process In: Miransari M (ed) Soil Tillage and Microbial Activities, Research Singpost, Kerala, India pp 111-143

Yoshida T (1975) Microbial Metabolism of Flooded Soils. In: Paul EA, MacLaren AD (eds) Soil Biochemistry Vol. 3, Marcel Dekker, New York pp 83-122

Zhang N, He X, Gao Y, Li Y, Wang H, Ma D, Zhang R, Yang S (2010) Pedogenic Carbonate and Soil Dehydrogenase Activity In Response To Soil Organic Matter in Artemisia ordosica Community. Pedosphere 20:229-235

Zhao B, Chen J, Zhang J, Qin S (2010) Soil Microbial Biomass and Activity Response To Repeated DryingRewetting Cycles Along a Soil Fertility Gradient Modified By LongTerm Fertilization Management Practices. Geoderma 160:218-224 